\title{
Aspects of Language Error at Morphological Level in Students' Descriptive Texts
}

\author{
Septina Sulistyaningrum ${ }^{1}$, Elieza Tri Astuti ${ }^{2}$ \\ \{1'septinanazura@mail.unnes.ac.id, ${ }^{2}$ caelieza@gmail.com\} \\ 12 Department of Indonesian Language and Literature, Faculty of Languages and Arts, \\ Universitas Negeri Semarang
}

\begin{abstract}
Language contact that occurs within the students as bilinguals in the teaching of B2 (Indonesian) causes mutual influence between B1 and B2. This mutual influence can occur at every level of linguistics, one of which is the morphological level. Such matter can cause difficulties in the teaching of B2 and also be the source of language errors. Data on language errors that the students experienced in the language learning process need to be analyzed and clarified the type of error by the teacher and determined how to fix it afterward. The results of the language errors analysis can be used as feedback in improving language teaching. This article described aspects of language errors at the morphological level in students' descriptive texts. By using the qualitative descriptive method, 3 aspects of language errors were found at the morphological level, namely language errors at the level of affixation, language errors at the level of reduplication, and language errors at the level of compounding.
\end{abstract}

Keywords: languange error analysis, morphological level

\section{Introduction}

The teaching of Indonesian as a second language (B2) requires students to be skilled in using the language in all situations and conditions so that students are expected to get used to using Indonesian according to the rules. The use of Indonesian in accordance with the rules can be started from the family environment as an informal language teaching place, then in schools which are formal language teaching places [1]. Students as individuals who are categorized as bilinguals which use two or more languages in turn for different purposes are essentially bilingual contact agents. This contact generates a mutual influence on the rule of language between B1 and B2. This mutual influence can occur at every level of linguistics, one of which is the morphological level. This can cause difficulties in the teaching of B2 and is also become the source of language errors [2].

Language errors at the morphology level often occur in the descriptive text written by the students. Language errors need to be noted because they can affect the attainment of language teaching goals in schools [3]. Therefore, the efforts to minimize language errors are at the morphology level needed so that students do not repeat the same mistakes in writing a descriptive text [4]. The effort of language instructors to minimize or even eliminate language 
errors can be done through the activity of collecting error samples, identifying errors contained in the sample, explaining those errors, classifying those errors, and evaluating the severity of the errors.

Studies on language error analysis have been found considerably, such as (1) study of contrastive analysis that identifies the comparison of two languages. Trough this contrastive approach, it will be obtained the uniqueness of each language and through contrastive studies will also be able to reveal that the cultural differences (between the culture of the first language and the second language) have implications for differences in the manisfestation of the language [5], (2) analysis of language errors in the exposition text of high school students. Errors faound in the utterance or writing (written language) of students are an inseparable part of the teaching and learning process, because basically with the occurrence of error there is awearing that real learning has occurred [6], and (3) language errors at phonological level in short stories written by participants from middle school students [7]. Therefore, to add to the treasury of language knowledge and the latest study of language, this article describes aspects of language errors at the morphological level in the descriptive text written by Grade VII students.

\section{Research Method}

The data in this research are in the form of language errors in the description text made by the 7 th grade students of Junior High Schools in Central Java. The steps of language error analysis include: 1) collecting error samples, 2) identifying errors, 3) explaining errors, 4) classifying errors, and 5) evaluating errors [8]. The third step requires a data card to make it easier to write an explanation or description of the error that occurred. In the data card, there contained: a) data numbering, data sources from students' essays as well as the classification of language morphological errors and data numbers. b) citation containing the vocabulary to be analyzed. c) the error aspect containing the type of morphological level error aspects. d) analysis section containing language error analysis based on aspects of errors at the morphological level. The data of errors in the use of Indonesian language contained in descriptive text were collected through a descriptive essay writing test technique. The collected data were then analyzed qualitatively using the steps of the analysis mentioned above and described in a descriptive form [9].

\section{Results And Discussion}

Analysis of language error at the morphological level in VII grader students' descriptive text includes 3 aspects of errors, namely 1) language errors at the level of affixation, 2) language errors at the level of reduplication, and 3) language errors at the level of compounding.

\subsection{Language Errors at the Level of Affixation}

\subsubsection{Error in Determining the Root}

Students still make many mistakes in determining the original form of the word (root). Such thing happens because students assume that one is the correct original form of a word even though it is actually not. Besides, students often write without paying attention to the 
rules of standard Indonesian. The following is an example of error data in determining the root:

- Rasa hangat berbaur dengan lembutnya hembusan angin sore.

The word in bold is an error in determining the root, the word hembusan is an incorrect form of word as a result of determining the root incorrectly. The word is formed because the language user assumes that the root of the word is hembus, whereas the correct form of the root is embus. Therefore, the correct word formation is embusan.

- Waduk Goa Kreo sangat membuwat hati bahagia.

The word in bold membuwat is a wrong word form as a result of an error in determining the root. The word buat becomes buwat so that an error occurs for the word membuat becomes membuwat.

\subsubsection{Reduction of Cluster Error}

The phonemes / k /, / p /, / t /, and / s / which are not in the form of clusters and digraphs are reduced. Deviations in reducing phonemes which should not be reduced often occur in the use of Indonesian [10]. Based on the analysis that has been done, it turns out that no words are found in the reduction of phonemes in the students' descriptive texts.

\subsubsection{Phoneme Assimilation Error}

Phoneme Assimilation Errors in Indonesian is found to be a deviation from the rules of the phonemes in which the phoneme is not being reduced when it should have been reduced. The following is the phoneme assimilation error data in the grade VII students' descriptive texts.

-Pemandangan waduk Goa Kreo sangat mempesona.

The word in bold is a phoneme assimilation error, the phoneme / p / in the word pesona should have been reduced when merging the morpheme meN-. The phoneme assimilation error in the word pesona is that the phoneme not being reduced so that it forms mempesona which should be changed to memesona.

-Museum Ranggawarsito adalah tempat untuk mensimpan benda-benda bersejarah.

A word in bold is a phoneme assimilation error, phoneme / $\mathrm{s} /$ in the word simpan should be reduced when merging with the morpheme meN-. The phonemic assimilation error in the word simpan is not being reduced so it forms mensimpan that is supposed to be changed to menyimpan.

\subsubsection{Loss of Affixation Error}

Loss of Affixation Errors often occurs if the bound form added to the basic word or root will change the grammatical meaning (such as prefixes, infixes, confixes, or suffixes) of the bound morpheme form which is used to derive the word. There are affixes attached to the beginning (prefixes), there are at the end of the basic word (suffix), and there is inserted in the middle of the basic word (infix). Affixes that are often removed are prefixes (prefixes) and suffixes (suffixes).

- lampunya yang nyala disaat malam hari.

The word in bold is the loss of affixation error, the affix removal on the word nyala is the wrong word formation. In order to be correct the prefix me- on the word nyala must be written so that it becomes menyala.

— jagalah tinggalan bersejarah itu yang berada di kota Semarang. 
The word in bold is the loss of affixation error, affix removal in the word tinggalan is a wrong word formation. In order to be correct the prefix pen- of the word tinggalan must be written so that it becomes peninggalan.

\section{-burung-burung berterbangan.}

The word in bold is a mistake in choosing the morph of the word berterbangan from the root word terbang. The syllable starts with the syllable ter. The syllable ter ends with /er/, so that the prefix ber-changes to be be-if it is added with the word whose first syllable ends with ler/ then the prefix ber-which is added to the word terbang becomes beterbangan.

\subsubsection{Error in Selecting the Affixes}

The error in selecting the affixes often occurs in the bound form which when added to the root or basic form will change the grammatical meaning (such as prefixes, infixes, confixes, or suffixes). The choice or addition of affixes to the words in the description text greatly determines the meaning of the word formation [11]. So that the error in selecting the affixes will cause errors in the use of language in the description text of students. Following is the wrong selection of affix in the description text of VII grader students.

- Panser biru berkepanjangan dari pasukan semarang biru.

Word in bold represents the error in selecting the affixesof the word berkepanjangan in the use of prefix ber-, resulting in errors in affix selection that should not use a prefix. Therefore, the correct form is kepanjangan.

—ada kereta api kuno yang bisa kita naikkan.

Word in bold represents the error in selecting the affixes of the word naikkan in the use of suffix $-k a n$, resulting in errors in affix selection that should use suffix $-i$. Therefore, the correct form is naiki.

- mahkota berwarna putih hingga merah keungunan.

Word in bold represents the error in selecting the affixes of the word keungunan in the use of suffix -nan, resulting in errors in selecting the affix that should use suffix -an. Therefore, the correct form is keunguan.

- tempat bersantainya enak untuk ditiduri.

Word in bold in data number E221669 represents the error in selecting the affixes of the word ditiduri in the use of prefix $d i$ - dan sufix $-i$, resulting in errors in affix selection that should neither use prefix $d i$ - nor suffix $-i$. Therefore, the correct form is tidur.

\subsection{Language Errors at the Level of Reduplication}

Language errors at the level of reduplication in VII grader students' essays are dominated by writing errors, errors of meaning, and errors of formation. Following is the description of language errors at the reduplication level in the descriptive text of VII grader students.

\subsubsection{Formation Error}

Error reduplication in formation occurs due to errors in grammatical formation in repetition of word.

Kalau waktu makan dia berputar-putar di depanku sambil mengibas-ibaskan.......

The word in bold is language error at the level of word reduplication of mengibas-ibaskan which belongs to formation error. Grammatical form of mengibaskan is reduplicated to be mengibas-ibaskan which should be mengibas-ngibaskan. 
- senjata-senta peninggalan Belanda.

The word in bold is language error at the level of word reduplication of senjata-senta which belongs to formation error. Grammatical form of senjata is reduplicated to be senjatasenta which should be senjata-senjata.

\subsubsection{Writing Error}

Reduplication error in writing the form of repetition occurs because of an error in writing the form of reduplication that is incomplete and does not use hyphens, so that it deviates from the rules of writing reduplication word so that results in an error.

- Salah satu andalan andalan wisata kota semarang.

The word in bold is language error at the level of word reduplication of andalan andalan which belongs to writing error. The writing of andalan andalan deviates from the rules of writing full reduplication word which should be written fully and using hyphen, so that it becomes andalan-andalan.

- berbagai macam makanan dan $\boldsymbol{o l e h}^{2}$.

The word in bold is language error at the level of word reduplication of $o l e h^{2}$ which belongs to writing error. The writing of oleh ${ }^{2}$ deviates from the rules of writing full reduplication word which should be written fully and using hyphen, so that it becomes oleholeh.

\subsubsection{Meaning Error}

Meaning error in the form of reduplication occurs because of the use of words that are similar to the meaning of the reduplication words, thus causing meaning errors in repetition. This can be said to be ineffective sentences because of the waste of words [12]

—aku sangat senang sekali banyak teman-teman.

The word in bold is meaning error, it occurs because of the combination of word which has the same meaning with reduplication word, occured in words banyak teman-teman which is not necessarily repeated because there has been a word representing the meaning of the reduplication word namely the word banyak so that the correct form is banyak teman or teman-teman.

— terkadang banyak turis ${ }^{2}$ dari luar negeri.

The word in bold is meaning error, it occurs because of the combination of word which has the same meaning with reduplication word, occured in words banyak turis ${ }^{2}$ which is not necessarily repeated because there has been a word representing the meaning of the reduplication word namely the word banyak so that the correct form is banyak turis or turisturis.

\subsection{Language Errors at the Level of Compounding}

Language error at the level of compounding in students' essays is mainly combining error. Meanwhile, the error of reduplication and affixation were not found. Following is the errors found in the essays.

-Pemain Psis sendiri sudah banyak yang diambil dari luarnegri.\|

The word in bold is the error of compounding level in combining the word luarnegri which is wrong because of the compound words that should be written separately instead 
of merged. Compound words luarnegri are supposed to be written separately to be luar negeri.

- tempatnya berada di jawatengah.

The word in bold is the error of compounding level in combining the word jawatengah which is wrong because of the compound words that should be written separately instead of merged. Compound words jawatengah are supposed to be written separately to be jawa tengah [13].

\section{Conclusion}

The aspects of error language in using Indonesian language at morphological level found in VII grader students' essays about descriptive text include the aspects of error language at the level of affixation, reduplication, and compounding. The results of the analysis can be used by teachers as a language teaching improvement effort.

\section{References}

[1] Binti Ida Umaya, "No Title" Univ. Nusant. PGRI Kediri, vol. 01, no. 01, pp. 1-7, 2017.

[2] G. M. Johan, "ANALISIS KESALAHAN BERBAHASA INDONESIA DALAM PROSES DISKUSI SISWA SEKOLAH DASAR,” J. Pendidik. Bhs. dan Sastra, vol. 18, no. 1, Jul. 2018.

[3] U. S. Maret and J. I. Sutami, "ANALISIS KESALAHAN BERBAHASA INDONESIA SISWA SEKOLAH MENENGAH ATAS * Nur Endah Ariningsih, Sumarwati, Kundharu Saddhono PENDAHULUAN Salah satu keterampilan menulis yang dipelajari dalam mata pelajaran Bahasa Indonesia adalah menulis eksposisi di samping," vol. 1, pp. 40-53, 2012.

[4] W. Oktavia, "MORFOLOGI DALAM WACANA JUAL BELI DARING DI," no. 2, 2018.

[5] T. Nur, “ANALISIS KONTRASTIF DALAM STUDI BAHASA,” Arab. J. Arab. Stud., vol. 1, no. 2, p. 64, Dec. 2016.

[6] P. D. Yana, A. Widjajanti, M. Hum, F. Husniah, and M. Pd, "Siswa Kelas X SMA Nahdatul Ulama Genteng."

[7] P. T. Akhir and R. Riskanti, "Halaman persetujuan," no. Cmc, pp. 1-13, 2017.

[8] K. Rustipa, "Contrastive Analysis , Error Analysis , Interlanguage and the Implication to Language Teaching," Pengemb. Hum., vol. 11, no. April, pp. 16-22, 2011.

[9] B. D. Nurwicaksono and D. Amelia, "ANALISIS KESALAHAN BERBAHASA INDONESIA PADA TEKS ILMIAH MAHASISWA,” AKSIS J. Pendidik. Bhs. dan Sastra Indones., vol. 2, no. 2, pp. 138-153, Dec. 2018.

[10] J. S. Unpam and M. Wildan, “Jurnal Sasindo Unpam, Volume 2, Nomor 2, Juli 2015,” vol. 2, pp. $1-9,2015$.

[11] D. I. K. Agam and S. Barat, "Kesalahan afiksasi dalam bahasa indonesia tulis murid sekolah dasar di kabupaten agam, sumatera barat (," vol. 11, pp. 131-140, 2014.

[12] Zamzani, “jarkan kepada siswa sehingga sisw·a,” vol. IV, no. 2, pp. 41-52.

[13] K. Saddhono, "Language and superdiversity: Indonesians knowledging at home and abroad. By Zane Goebel." Soc. Stu. vol. 12 no.1 pp. 113-118, 2018 